\title{
Study Comparison of Plastic Waste Ocean Pollution Management Strategies Between Japan and Indonesia
} Elsa Ariana ${ }^{1 *}$, Khoirunnisa Indah Cahyani ${ }^{1}$,

\author{
M. Ghazy Ramadhan ${ }^{1}$, Irvan Yama Pradipta ${ }^{1}$, Indra Jaya Wiranata ${ }^{1}$
}

\author{
${ }^{1,}$ International Relations Department, Universitas Lampung \\ *Corresponding Author. Email: elsa.ariana1011@students.unila.ac.id
}

\begin{abstract}
This paper describes the idea of a comparison of the policy framework of the ocean pollution management strategy, involving G20 member countries, especially countries in the Asian region with a sample of developed and developing countries that have the largest archipelago in Asia, as part of an effort to realize the G20 Marine Pollution Agreement and SDGs Point 14. Researchers present how the condition of the waste problem and the comparison of waste management strategies carried out by each country can affect SDGs Point 14. This study uses a comparative research method and uses the Gephi mapping tool to see the direction of policy differences that arise from the results comparison. In Indonesia, as a developing country and the owner of the largest archipelago compared to Japan, representative of developed countries, the focus of waste management is more on domestic strengthening and focusing on each region in each region of Indonesia. Meanwhile, Japan as a developed country already has a cultural maturity in waste management. Therefore, by staying focused on the country, Japan has also begun to take a stance to plunge into global waste management.
\end{abstract}

Keywords: Plastic waste, management ocean, Japan, Indonesia

\section{INTRODUCTION}

Indonesia and Japan are the two largest archipelagic countries in Asia and are members of the G20 (Group of Twenty) where Japan and Indonesia are member countries originating from Asia other than South Korea. The G20 is an international forum formed for cooperation in the global economy, health, environment and various global issues[1]. In the post2008 global financial crisis, the agenda and focus of the G20 expanded not only on finance but also on social, economic and development issues, throughout the year the members of the G20 were Argentina, Australia, Brazil, Canada, China, France, Germany, India, Indonesia, Italy, Japan, Republic of Korea, Mexico, Russia, Saudi Arabia, South Africa, Turkey, United Kingdom, United States of America and European Union. Hold meetings and discuss issues that are their focus.

In 2019 the G20 meeting resulted in an Agreement regarding marine pollution. The agreement is in the form of an implementation framework for actions on marine plastic waste which contains two main points[2]. First, facilitate the implementation of an effective plan that contains information sharing between G20 member countries and implementation of real actions. Second, collaborative action and expansion of the implementation of action plans in the form of promotion of international cooperation, promotion of solution-innovation, exchange of information and knowledge and multi-involvement stackholder and awareness raising. The agreement, which was agreed in June 2019, departed because of the increasing problem of marine waste, especially plastic and micro-plastic waste.

Based on data from Ocean Crusaders.org, Indonesia is the second of twenty countries that produce plastic waste pollution in the sea[3]. This data shows that Indonesia's marine pollution management strategy is still not successful. In addition, Japan shows that marine plastic waste is less and has been organized than Indonesia by not including Japan in the 20 largest countries in marine pollution. Japan, which is a developed country with 
very good technology, society and infrastructure, is one of the supporting factors why waste pollution in Japan is better managed than Indonesia, which is still a developing country with all the problems of infrastructure, society, etc. that still need a lot of improvement. With the status of the largest archipelagic country in Asia, the sea, which is the largest area in the two countries, should be the main focus in its maintenance.

At SDGs point 14 Live below water, the SDGs target the conservation and sustainable use of marine, ocean and maritime resources for sustainable development[4]. By increasing scientific knowledge about marine health marine technology and providing access to marine resources and increasing the conservation of sustainable use of the sea. With the continued increase in the amount of plastic waste in the sea, through SDGs 14 as an effort to protect marine ecosystems against the increasing threat of marine debris and unsustainable use of marine resources[5].

In reducing marine waste, real actions are carried out through SDGs 14, namely[6]. Changes in consumer behavior and the single-use plastic industry and the application of waste management on land and at sea . Indonesia and Japan, which are both members of the G20 in achieving SDGs point 14, have a Policy framework with a different focus onmanagement strategies Ocean pollution as developing and developed countries.

In policy framework, Japan's focus is more on controlling marine plastic waste in the world.

\section{METHOD}

Method used in this study is a qualitative method. This qualitative method refers to the data contained in reading materials that have been researched by previous researchers and written sources on the official website. By using this qualitative method, it aims to explain a phenomenon by describing and collecting data from available research materials to help complete this research, or referred to as objectives exploratory. The purpose of using qualitative methods is also useful for understanding and building new knowledge behind the available data, both logical empirical truths and sensual empirical truths. In this qualitative method, data collection uses the variables Policy framework related to ocean plastic pollution management used by the Japanese and Indonesian governments. The variable Policy Framework used in this study is a Policy framework that was implemented in response to the report of the G20 meeting in action against marine plastic waste in 2019[7]. Using this qualitative method, the national and international sectors will be used. In the national sector, Japan carries out promotion, prevention, and innovation in waste management systems, in the international sector, Japan conducts collaboration, international cooperation and surveys on waste knowledge with Stackholders and other countries. Indonesia, which is the focus of the policy framework, is more of the national sector where the national policy strategy involves various government structures, both national and regional, in waste management[8].

So from the explanation above, we hypothesize that, themanagement strategy Ocean pollution between Japan and Indonesia as developing and developed countries in achieving SDGs 14 points has a difference in the focus of the Policy framework applied in each country. In this study, there is a problem formulation, namely, How is the Ocean Plastic Pollution management strategy between Japan and Indonesia? In this study, researcher aim to compare the management strategies of Ocean Pollution between Indonesia and Japan, as the representative of archipelagic developing and developed countries, to see the impact of the success of each country's policies on the achievement of SDGs point 14 Live below Water.

Get the results of the research in the form of descriptions and interpretations in the context of a comparison between two countries, Japan and Indonesia, regarding the management of Ocean plastic pollution.

\section{LITERATURE REVIEW}

Marine pollution that occurs has a huge impact on human development in the vicinity. This is because water is the main source of life, so if the water is polluted by waste, one of which is plastic, it will disrupt the existing ecosystem and become a cycle that keeps on repeating so that the cycle chain must be broken so that marine pollution can be resolved. Polluted sea water from waste generated by human activities mostly occurs in the economic sector such as production, consumption, etc., resulting in the contamination of resources and living things such as marine biota, fauna that live on land to plants, so that resources and living things are polluted. This can interfere human development with existing. However, human development can also be something that accelerates the phenomenon of ocean pollution, because the human need for high resources causes over exploitation of resources, causing a lot of waste due to the exploitation of resources. Ocean pollution is a phenomenon that is said to be a nonpoint source, meaning that this phenomenon tends to be difficult to identify where the waste comes from, but that does not mean that the waste cannot be identified where the waste comes from. Waste in the sea can be identified into several groups, in this case plastic is categorized as waste along with battery waste, paper, cardboard, etc. The classification of the waste can make it easier to identify the waste itself 
In SDGs point 14 , the intended sustainable development goal is about marine ecosystems. The existence of this goal focuses on joint handling of actions to protect beaches and oceans and the resources contained in them from waste or marine debris, including plastic waste that pollutes ecosystems. In fact, $80 \%$ of the pollution in the oceans comes from activities on land, and human activities are no exception. In this regard, every country experiences the same problem to overcome the problem of marine debris. especially for industrial countries and coastal countries that dispose of industrial waste and other wastes directly into the surrounding oceans without a clear policy for handling the waste. Therefore, in SDGs point 14 regarding marine ecosystems, there is one achievement target that must be immediately completed by both the central and local governments which contains " 14.1 by 2025, preventing and reducing all types of marine pollution, especially those originating from activities on land, including marine debris and food contamination".

The history of plastics began in 1910 when the American scientist Leo Baekeland made plastic the material that became the chemical development of plastics with easy composition[9]. Plastic is a cheap, lightweight and durable material that replaces traditional materials such as bamboo, cloth, minerals and sea shells. But plastic is very difficult to decompose naturally. With increasing population growth, economies and some developing countries there has been a drastic increase in the use of plastics. Now plastic waste always ends up in the sea and produces various problems.

Pollution of marine plastic waste has become one of the world's main focuses, this happened in 2015 when a biological researcher recorded how plastic impacts one of the marine biota, namely turtles. This is the beginning of the attention of all countries on the impact of plastic waste pollution in the sea. In 2016 there were an estimated 275 million tons of plastic waste that is reproduced throughout the world and about 4,8- 12.7 million tons ended up in the sea[10] This figure continues to increase every year and it is estimated that by 2050 there will be more plastic waste in the ocean than fish by weight. It is suspected that the largest plastic waste comes from countries in Asia Pacific.

The Japanese government's policy in dealing with the problem of plastic pollution, issued a taxation policy for each plastic product and shopping plastic as one of the reductions in the use of singleuse plastic. Meanwhile, in local governments such as in ktoa Sayama and Saitama prefectures, strengthening planting in communities, especially those who travel in seaside areas to be able to bring home the plastic waste they carry with one of their campaign symbols using the logo of a crying whale to gain sympathy from the community. This movement eventually spread to all regions of Japan and even encouraged several areas such as the city of Kameoka to be able to carry out a policy of banning the use of plastic bags. The Indonesian government's policy in dealing with plastic problems is more focused on the management of handling waste originating from plastic waste. Plastic waste management is spread throughout Indonesia and is commonly referred to as a waste bank. In addition, it also implements a system so that waste can be recycled into a product that has use value.

In addition to the policies of each country above, in 2019 Japan and Indonesia also issued the same policy framework for ocean pollution management in their respective countries. this is a form of action from their joining into the G20 organization which is an international regime that handles economic and other matters. The policy framework produced by the G20 is different for each country because the rules and policies are adapted to the conditions in each country.

\section{ANALYSIS}

\subsection{Japan Policies}

Plastic is one of the most important things in everyday life. However, it also has a long-term negative impact on the environment, especially the sea. Currently it is known that there are millions of plastic waste that becomes waste in the oceans and the number is increasing every year. Therefore, Japan responded to this by using the Marine Plastic Waste Strategy Policy which was formulated in 2019 by focusing on preventing the release of plastic waste into the sea with the following 8 areas. 1. Promotion of proper waste management systems, 2. prevention of littering, 3. Collection of plastic waste on land 4. Recovery of plastic waste in the oceans, 5. Cooperation with stakeholders. 6.Innovation in the development of Alternative materials .7. International cooperation to promote action in developing countries. 8. Survey of actual situation[11].

\subsubsection{Promotion of Proper Waste Management}

In promoting the handling of waste, the Japanese government started by collaborating with the Nippon Foundation which covers the public and private sectors. In the survey itself is known that for $80.9 \%$ of the public is very aware of the dangers of plastic waste on marine permasalahn but less know in more detail[12] They have a high desire to reduce plastic waste, but the lack of activities related to reducing plastic waste makes their interest confused about it. In the process itself, plastic will always reach the ocean unless someone picks it up and throws it in the trash. Because of that, it can now be done in an easy way such as 
cleaning the surrounding area, especially roads and rivers.

\section{Prevention of littering}

In preventing littering, the Japanese Ministry of Environment has increased the budget to support programs both nationally and regionally. In addition, there is also a policy from the government in prohibiting the use of single-use plastic and the wise use of plastic by the public. In the continuation of the program itself, it depends on the extent to which each region will implement it. For example, several prefectures such as Tokyo, Okinawa, and Toyama have imposed a fee of 5 yen for plastic groceries in all supermarkets, which resulted in the suppression of the use of wholesale plastics by $90 \%$ because people choose to bring their own shopping bags[13].

\section{Collection of scattered waste on land}

In doing this The government Japanese implements the 3R (Reduce, Reuse, Recycle) strategy. Every week, thousands of plastic waste boxes placed along the road will be picked up and collected for recycling. By focusing on crushing, compacting and washing, by passing ansorter automatic with a magnet that will separate waste that contains Metal. Plastic that has been solidified will be able to be recycled into various more useful things[14].

\section{Recovery of Plastic litter in the Oceans}

In carrying out the recovery of waste that is already in the ocean, the Japanese government conducts special cooperation with fishermen and communities around the coast, a group of people will work to keep the beach clean, garbage usually consists of plastic bottles, chemical waste tanks, medical waste, most of the waste. come from outside Japan if seen from the writing usually is garbage from Korea[15]. The reason coastal communities are very diligent in cleaning up trash is due to a shift in the waste itself. In the past, waste that was thrown into the sea would disappear and blend with nature because the waste was still organic, while now garbage is no longer just that. In addition, because of the news that spread that garbage from Japan washed up in the Hawaiian Sea, it caused a very embarrassing feeling for the Japanese people.

\section{Cooperation with Stakeholder}

Cooperation with several industries in reducing plastic waste, such as what happened with Disney Land Japan prohibiting the use of plastic waste and disposable drinking water bottles, McDonald's replacing plastic bags with paper bags, several large restaurants in Japan replacing plastic straws with straws made from bamboo to be more hygienic[16]. Many stakeholders have made changes in responding to the problem of plastic waste, mostly reducing or prohibiting the use of disposable plastic tools.

5. Innovation in development conversion to alternative materials

In processing plastic waste into alternative materials, Japan has made use of plastic waste which is used as an energy resource in The Showa Denko Factory, which is a form of recycling that uses chemical methods by breaking down the plastic constituents. which consists of carbon and hydrogen by dissolving plastic into basic gas, if in the systematic process itself it will be done like this, the gas will be flowed into asepana furnace 1,400 with an oxidized process that will produce hydrogen and carbon monoxide which is then cooled to -200 degrees Celsius which will then undergo a cleaning by removing harmful substances such as hydrogen chloride and sulfur and converting carbon monoxide into Hydrogen and Carbon dioxide. Hydrogen will be supplied to the factory and converted into ammonia which will be used as medicine. While carbon monoxide is supplied to the carbonated beverage plant[17]. Because of that, the products that are drunk by the people here come from recycling factories.

6. International Cooperation for Promoting Measures in Development Country

In carrying out international cooperation to promote action against plastic waste in the sea. Japan cooperates with IGES (Institute for Global Environmental Strategies), UNESCAP (United Nation Economic and Social Commission for Asia and the Pacific), and G20 (Group of Twenty)[18]. By trying to help and provide innovation in preventing plastic waste in the ocean, appointing four developing countries in the ASEAN region (Indonesia, Thailand, Malaysia, and Vietnam)[19] to develop their local actions and plans regarding the management of plastic waste.

\section{Survey on Actual Situation}

In obtaining data on the actual situation and monitoring the level of pollution in the seas of Japan using the Method Ocean Monitoring. Countercontrol here is defined as an effort to obtain and provide from direct observation data to be able to determine the level of the marine environment in a country. There are many ways to conduct marine surveillance and will be presented in Figure 1:

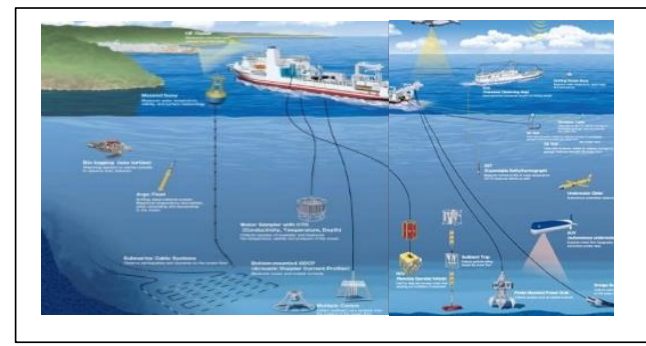

Figure 1 Ocean Monitoring. 


\subsubsection{Indonesian Policies}

For Indonesia, marine waste in the form of plastic is a problem that is a never-ending focus. Because the world problems that Indonesia is also facing are very difficult to solve for both the government and the community. Terbutkti according Jambeck et al 2015, Indonesia was in second after China with the country's top contributor to marine debris scattered in the world that is as much as 0.48 to 1.29 tonnes / year[20] As a step to reduce plastic waste, Indonesia has issued the following policies.

\section{Ministries and Coordination Mechanism: Indonesia}

In accordance with the Decree of the President of the Republic of Indonesia Number 83 of 2018 concerning Marine Debris Management, in 2018, which mandates to establish a National Coordination Team for Marine Debris Management. The team is chaired directly by the Coordinating Minister for Maritime Affairs and the Minister for the Environment and Forestry, who serve as daily chairmen. This coordination team also includes 14 ministers, cabinet secretaries, and the head of the Maritime Security Agency as members. The inclusion of other Ministries is expected to synergize in solving this plastic waste problem, both in infrastructure, waste management, and so on. In general, the formation of this national coordination team certainly has a specific purpose. The aims are:

- Coordinate the activities of ministries, nonministerial institutions, local governments, communities, and/or the private sector regarding marine waste management,

- Making policies to overcome obstacles and solve problems regarding marine debris management, and

- Coordinate monitoring and evaluation of the implementation of the action plan[21].

\section{Acceleration of controlling and restoring Citarum} River pollution and degradation (Regulated by Presidential Regulation No. 15/2018)

Presidential Regulation of the Republic of Indonesia number 15 of 2018 concerning acceleration of pollution control and damage to the Citarum River watershed which consists of 21 articles has been promised by the local government quickly in holding various activities to restore the quality of the Citarum River back to being clean and odorless as mandated by the Presidential Regulation. activities that by making mapping and starting to reorganize, tree planting activities are expected to be able to restore the function of the Citarum ecosystem. In addition, socialization is also carried out to residents around the riverbanks not to litter and are expected to take part in accelerating pollution control[22].

3. Acceleration of Waste-to-energy projects in $\mathbf{1 2}$ cities (Regulated by Presidential Regulation No. 35/2018)

The Jabodetabek area is known as an area that does not stop waste. Among several strategies that the government has planned to deal with this problem is the development of waste-to-energy (WTE) technology for the capital city and three other cities, namely, Tangerang, South Tangerang, and Bekasi. These four areas are among the 12 cities and regencies that are prioritized based on Presidential Regulation (Perpres) No 35/2018 regarding the acceleration of the construction of thermal generating facilities to convert waste into electricity with environmentally friendly technology. One of the projects being built in Tangerang, which is predicted to be completed in 2022, is an energy processing plant. However, in the development process, there are still questions regarding the smoke stack required for the factory to be about 80 meters high, which is considered higher than the maximum limit of 46 meters set for the flight operational safety area (KKOP) around Soekarno-Hatta International Airport, which is less than 30 feet away. than 20 kilometers from the project site. The factory is considered to have the ability to burn 1,500 tons of waste a day and is projected to generate up to 20 megawatts of electricity[23].

4. National Plan of Action for Combating Marine Litter 2018-2025 (Regulated by Presidential Regulation No. 83/2018)

In accordance with Presidential Regulation No. 83/2018 regarding Indonesia's action stating the National Action Plan for Marine Debris Management 2018-2025 involving the synergy of 16 Ministries, Local Governments, Private Sector, and NGOs with a total budget of USD 1 billion. In addition, Indonesia and 17 other countries under the East Asia Summit will declare about fighting marine plastic waste and reducing a minimum of $25 \%$ from the sea waste boundary. Indonesia is also committed to using plastic waste collected from the sea to replace $5 \%-7 \%$ bitumen (Asphalt) for road construction, starting 2018-025. Indonesia will also build infrastructure for TPA in the context of waste processing. In addition, the Ministry of Environment, Local Government, and Society/NGOs will promote 40 local government laws and promote by 2025 to stop using plastic bags in shopping centers[24].

5. Funding mechanisms for the National Plan of Action (NpoA)

In the funding mechanism for this national action to reduce plastic waste, funding sources are obtained from various parties, ranging from . National budget (APBN and APBD) 2. Public Private Partnership (PPP) and CSR (BUMN) 3. Bilateral \& Regional Cooperation 4. International 
Organization Supports (WB, GEF, UNEP) 5. NGO, Volunteer, and Communities Support 6. Blended Finance. From this source of funds, it is hoped that it can help realize projects that have been planned by the government, both in the short and long term. Some national action done is change behavior patterns people not to litter, garbage processing mechanisms that are effective, as well as increasing the good cooperation with the private sector, international organizations, as well as other countries[25].

\subsection{Mapping The Reach of The Japanese and Indonesian Policy Frameworks}

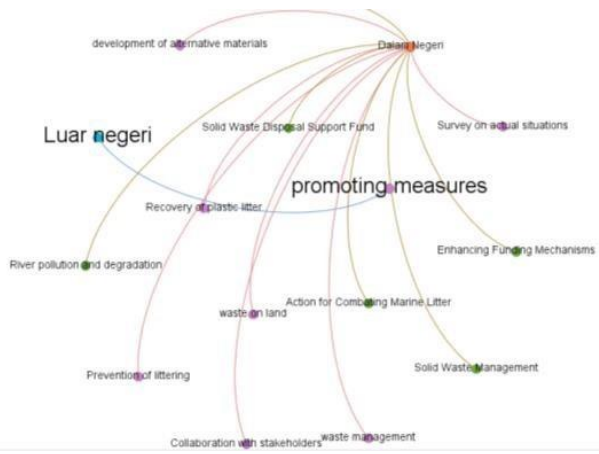

Figure 2 Map of the japanese and indonesian policy frameworks range

Description:

- Purple node : Japanese Policy Framework

- Green node : Japanese Policy Framework

- Orange node: coverage of domestic policy framework

- Blue nodes: the reach of foreign policy frameworks

- $\quad$ Font size of nodes: modularity

The mapping results from Gephi conducted show that the majority of policy frameworks from both countries, namely Japan and Indonesia, are still focused on handling marine pollution, especially domestic waste. It can be seen from the orange node which is the center of almost all existing policy frameworks. However, it also appears that one of the Japanese policy frameworks that targets international reach is the policy framework promoting measure. The policy framework is known to be a Japanese policy to conduct promotions related to waste measurement targeting developing countries. This phenomenon is also identified as modularity where there are different variants and creates a new environment in it. This means that, in this case, Japan's policy framework has shown a different reach from Indonesia, where the reach is wider by targeting the international community.

\subsection{The Results of The Discussion}

The attitude of Indonesia and Japan, which are both involved in managing marine debris, is a manifestation of their attitude as a global community that must deal with waste problems which are global problems so that solutions must be carried out together. Through green theory that focuses on environmental problems, and presents an action so that humans contribute in dealing with problems related to all kinds of problems such as economics, the environment. So it happened because of the awareness of Japan and Indonesia on this marine debris issue which resulted in a real action and contribution. One of them is by being active in the G20 organization and the agreement made as a form of handling plastic pollution in the ocean. The agreement was adopted by each country into their respective institutions and also gave rise to a different focus where Japan focused on dealing with policies aimed at overseas and domestically while Indonesia focused more on this domestically. It is clear that the existing implementation of the G20 agreement on plastic pollution is due to the power of the international organization. According to Robert $\mathrm{O}$ Keohane and Lisa Martin that states and international organizations have an interdependence relationship because of a institutions or organizations that serve as a place to exchange information with each other, contribute to helping deal with each other's problems, make more credible commitments and as a feedback operation facility. This interdependence relationship can be seen from the joining of Indonesia and Japan into the G20 which turned out to have a good impact on the two countries. Japan and Indonesia can learn about various ways to deal with all forms of marine debris problems. The way Japan and Indonesia deal with marine debris issues with the G20 is by exchanging information with various members of the G20. Not only in the field of exchanging information, but developing various kinds of actions in dealing with marine debris problems.

\section{CONCLUSION}

The difference in policy direction between Japan and Indonesia in managing plastic pollution in Ocean is influenced by other factors such as culture and GDP. The culture of high awareness of waste disposal in its place in Japan is a factor that influences Japan's success in dealing with waste problems. In addition, it is also due to the high opinion of Japan and technological advances in Japan which are superior to Indonesia.

\section{REFERENCES}

[1] G20 2020 Saudi Arabia "G20 2020 Saudi Arabia", https://g20.org/en/Pages/home.aspx. (accessed October 28, 2020)

[2] "The G20 | DFAT, https://www.dfat.gov.au/trade/organisations/g20/P ages/g20. (accessed October 28, 2020)

[3] Administrator, "Tujuan 14 SDG Indonesia" https://www.sdg2030indonesia.org/page/22tujuan-empatbelas. (accessed October 28, 2020,) 
[ 4 ] Administrator, "Tujuan 14 SDG Indonesia" https://www.sdg2030indonesia.org/page/22tujuan-empatbelas. (accessed October 28, 2020,)

[5] Ocean Care, "Marine Debris and The Sustainable Development Goals"

[6] Ocean Care, "Marine Debris and The Sustainable Development Goals"

[7] G20 Member, "G20 Implementation Framework for Actions on Marine Plastic Litter". Juni. 2019

[8] G20 Member, "G20 Implementation Framework for Actions on Marine Plastic Litter". Juni. 2019

[9] Ocean Policy Research Institute, "White Paper on the Oceans and Ocean Policy in Japan,”. 2019.

[10] Ocean Policy Research Institute, "White Paper on the Oceans and Ocean Policy in Japan,". 2019.

[11] G20 Member, "G20 Implementation Framework for Actions on Marine Plastic Litter", https://www.mofa.go.jp/policy/economy/g20_sum mit/osaka19/pdf/documents/en/annex_14. (accessed October 28, 2020).

[12] Ocean Policy Research Institute, "White Paper on the Oceans and Ocean Policy in Japan,”. 2019.

[13] Ocean Policy Research Institute, "White Paper on the Oceans and Ocean Policy in Japan,”. 2019.

[14] Ministry of the Environment, “海羊プスチりクコ文策》 ションプン, Japan, 2019, 5-6.

[15] "Japan to Collect All Types of Plastic Waste for Recycling," The Japan Times, https://www.japantimes.co.jp/news/2020/07/22/ national/japan-plastic-waste-recycling/. (22 Juli 2020)

[16] Ocean Policy Research Institute, "White Paper on the Oceans and Ocean Policy in Japan,”. 2019.

[17] Tim Hornyak, "Plastic Fantastic: How Does Tokyo Recycle Its Waste?," The Japan Times, (10 Juni 2017)

[18] Dr Yasuhiko Hotta dkk., "Designing Policies towards OSAKA Blue Ocean Vision,” 2019, 18.

[19] Dr Yasuhiko Hotta dkk., "Designing Policies towards OSAKA Blue Ocean Vision,” 2019, 18.

[20] J. R. Jambeck, R. Geyer, C. Wilcox, T. R. Siegler, M. Perryman, A. Andrady, R. Narayan, K. L. Law, "Plastic Waste Inputs From Land Into the Ocean. Science page. 771 (2015).

[21] Government of Indonesia (2018), "Peraturan Presiden Republik Indonesia Nomor 83 Tahun 2018 tentang Penanganan Sampah Laut.) https://sipuu.setkab.go.id/PUUdoc/175608/P erpres\%20Nomor\%2083\%20Tahun\%202018.pdf (accessed 23 October 2019).

[22 ] Forest Digest, 2009." Mengatasi Tuna Daya Mengelolah Citarum". https://www.forestdigest.com/detail/263/mengat asi-tuna-daya-mengelola-citarum (diakses tanggal 10 November 2020.)

[23] USAID, 2019." Construction of Greater Jakartas Waste to Energy Plants Underway". https://www.iced.or.id/en/construction-of- greater- jakartas-waste-to-energy-plants- underway/ (diakses tanggal 10 November 2020.)

[24] Osaka Blue Ocean Vision, 2017." Indonesia: Actions and Progress On Marine Plastic Litter", https://g20mpl.org/partners/indonesia (diakses tanggal 11 November 2020)

[25] Nani Hendiarti,"Combating Marine Plastic Debris in Indonesia". Science to Enable and Empower AsiaPacific, Jakarta 2018 